
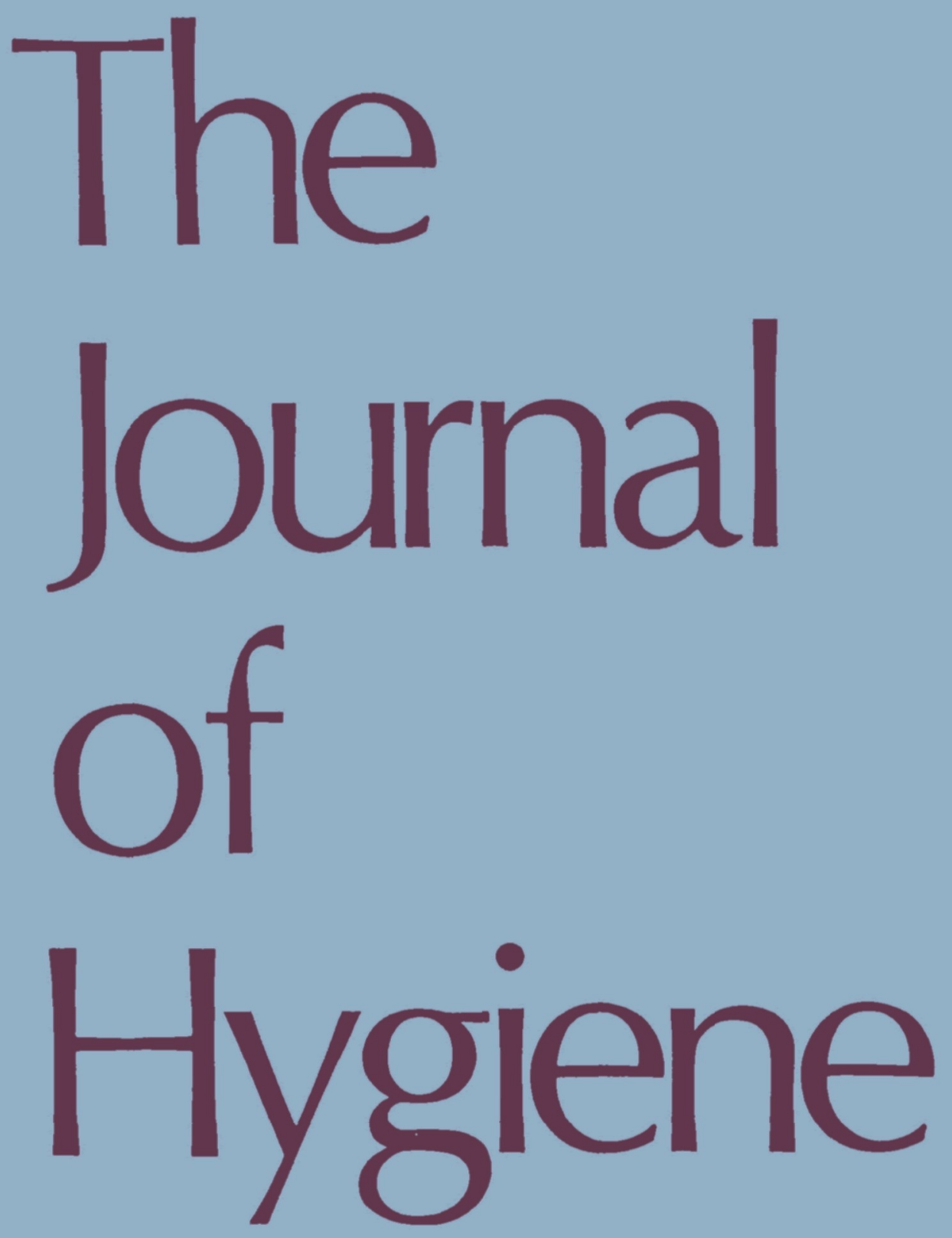

VOL: 88 NO: 2

APRIL 1982 


\title{
The Journal of Hygiene
}

\author{
EDITED BY \\ J. R. Pattison \\ Professor of Medical Microbiology \\ King's College Hospital Medical School \\ M. J. Lewis \\ Director, \\ Public Health Laboratory, \\ Nottingham \\ J. H. McCoy \\ Formerly Director, \\ Public Health Laboratory, \\ Hull \\ W. C. Noble \\ Professor of Microbiology, \\ Institute of Dermatology, \\ London
}

\section{IN CONJUNCTION WITH}
M. J. Anderson (London)
A. B. Christie (Liverpool)
Anna Hambraeus (Uppsala)
C. R. Madeley (Newcastle upon Tyne)
J. Nagington (Cambridge)
M. B. Skirrow (Worcester)
R. S. Tedder (London)
Sir Graham Wilson (London)
R. D. Barry (Australia)
R. J. Gilbert (London)
O. M. Lidwell (London)
R. R. Marples (London)
J. Oxford (London)
C. C. Spicer (Exeter)
A. T. Willis (Luton)

The Journal of Hygiene publishes reports of research and original findings in subjects related to infectious diseases. Particular emphasis is given to the epidemiology, prevention and control of such diseases, but the field covered is broad and includes the microbiological, virological, immunological, clinical and social aspects of infectious diseases of man and animals.

(c) Cambridge University Press 1982

\section{PERMISSIONS}

\section{Copying}

This journal is registered with the Copyright Clearance Center, 21 Congress Street, Salem, Mass. 01970. Organizations in the U.S.A. who are also registered with the C.C.C. may therefore copy material (beyond the limits permitted by sections 107 and 108 of U.S. copyright law) subject to payment to C.C.C. of the per-copy fee of $\mathbf{8 0 2 . 0 0}$. This consent does not extend to multiple copying for promotional or commercial purposes. Code 0022-1724/82/2828-0001 $\$ 02.00$.

ISI Tear Service, 3501 Market Street, Philadelphia, Pennsylvania 19104, U.S.A., is authorized to supply single copies of separate articles for private use only.

For all other use, permission should be sought from the Cambridge or New York offices of the Cambridge University Press.

\section{SUBSCRIPTIONS}

The Journal of Hygiene (ISSN 0022-1724) is published annually in two volumes of three parts.

The subscription price of volumes 88 and 89,1982 , is $£ 29$ net (U.S.A. and Canada US \$80) per volume (post free); single parts are available at $£ 12.50$ net (U.S.A. and Canada US 834) plus postage. Back volumes are also available. Orders, which must be accompanied by payment, may be sent to any bookseller or subscription agent or to Cambridge University Press, The Edinburgh Building, Shaftesbury Road, Cambridge CB2 2RU, or in the U.S.A. and Canada to Cambridge University Press, 32 East 57th Street, New York, N.Y. 10022. Second class postage paid at New York, N.Y., and at additional mailing offices. POSTMASTER: send address changes in U.S.A. and Canada to Cambridge University Press, 32 East 57th Street, New York, N.Y. 10022.

Claims for missing issues should be made immediately on receipt of the subsequent issue. 